\title{
USING WATER EXTRACTS OF SOME ALLELOPATHIC PLANTS ACCOMPANIED WITH A REDUCED RATE OF GLYPHOSATE FOR CONTROLLING BROOMRAPE IN FABA BEAN
}

\author{
T.S. Mohamed(1), A. A. H. Sharshar(2) and S. H. E. Hamada(3) \\ (1) Food Legumes Research Department, Field Crops Research Institute, ARC, Egypt. \\ (2) Weed Survey, Ecology and Physiology Department - Weed Research Central \\ Laboratory, ARC. Giza. Egypt. \\ (3) Plant Protection Department - Faculty of Agriculture Al-Azhar University, Cairo, Egypt.
}

Received: Mar. 25, 2021

Accepted: Mar. 31, 2021

\begin{abstract}
A field experiment was conducted on an Orobanche naturally infested soil at Sakha Agricultural Research Station - Kafr El Sheikh, in 2017/2018 and 2018/2019 seasons aiming at combating Orobanche crenata in faba bean through using water extracts of fenugreek, coriander and sorghum crops, each at a concentration of $10 \%$ weight/volume at a rate of 20 litres/fed mixed with glyphosate (48\%) at a reduced rate $(40$ $\left.\mathrm{cm}^{3} / \mathrm{fed}\right)$ compared to the recommended rate of the same herbicide $\left(75 \mathrm{~cm}^{3} / \mathrm{fed}\right)$. Treatments were foliarly applied twice at $\mathbf{5 0}$ and $\mathbf{7 0}$ days after sowing. Two faba bean Orobanche tolerant cultivars (Misr 1 and Giza 843) and a susceptible one (Sakha 1) were used in this study. The experiment was laid out in a split plot design with three replications. The cultivars were randomly devoted to the main plots while broomrape control treatments were randomly arranged in the sub plots. The results showed significant reductions in Orobanche spikes number and weight at harvest on the three cultivars due to all treatments applied with no significant differences among them. Misr 1 and Giza 843 cultivars were inferior to Sakha1 cultivar in number and weight of broomrape spikes $/ \mathrm{m} 2$, but they were superior in yield and its components. Therefore, foliar application of either fenugreek, coriander or sorghum plant extracts as donor allelopathy at a concentration of $10 \% \mathrm{w} I \mathrm{v}$ at a rate of 20 litres mixed with glyphosate herbicide (48\%) at a rate of $40 \mathrm{~cm}^{3} /$ fed applied twice 50 and 70 days after sowing can help in controlling Orobanche crenata and improve faba bean yield especially for susceptible genotypes.
\end{abstract}

Key words: Faba bean, Glyphosate, Allelopathic, Orobanche crenata, Fenugreek, Sorghum, Coriander.

\section{INTRODUCTION}

Faba bean is a major food and feed legume in different parts of the world Rubiales (2010). In crop rotation, faba bean plants play an important role in improving productivity of the following cereal crops through the biological nitrogen fixation Fouad et al., (2013). In Egypt, the average area cropped to faba bean during 2015 to 2019 was 103667 feddan with a seed yield average of 9.2 ardab/feddan (one ardab $=155 \mathrm{~kg}$ ), and total production of about 155 thousand metric tons, which covers about $32.6 \%$ of the total national consumption*. One of the major constrains to faba bean cultivation in the Mediterranean and West Asia is broomrape parasitic weed (Orobanche crenata) as mentioned by Maalouf et al., 2011. Orobanche crenata is an obligate root parasitic flowering plant devoid of 
chlorophyll and completely dependent on the host plant for its nutritional needs Fernandez-Aporicio et al., (2016). In Egypt, Orobanche crenata causes great damage and notable yield losses to faba bean crop. Ennami et al. (2017) stated that Orobanche crenata populations collected from faba bean plants were more aggressive and virulent not only on faba bean but also on some other crops such as lentil. Facing this problem, research activities on 0 . crenata control were intensified in many aspects. The control strategies based on cultural practices and biological control were not enough Habimana et al., (2013). It was reported, in breeding legumes for 0 . crenata resistance little success has been achieved. However chemical control of $O$. crenata in faba bean was successfully used Rubiales et al. (2012). In this connection, allelopathy is considered one of the possible alternatives for achieving sustainable weed management Farooq et al., (2011). Using water extracts of allelopathic plants accompanied with reduced rates of imazapyer and glyphosate herbicides for controlling weeds in arable crops has become a well-established fact Jabran et al., (2008). Plants express their allelopathic capability through production of allelochemicals and their exudation into the environment by volatility, leaching and decomposition Farooq et al., (2011). For instance, reduced dose (half) of herbicide (Trifluralin $1.2 \mathrm{~L}$ ha-1) when tank mixed with allelopathic water extracts of sorghum crop proved weed control in broad bean Alsaadawi et al., (2013). Also they concluded that all parts of sorghum plants such as roots, leaves and stems as well as germinating seeds release phyto-inhibitors that can affect weed growth. Madany and Khalil (2017) reported that fenugreek seed extract up to $1.0 \%$ (W/V) efficiently enhanced growth as well as chlorophyll content of faba bean. Although a lot of information is known about the allelopathic potential of sorghum and fenugreek is available, but little information regarding allelopathic potential of coriander. Therefore, the present study was designed to assess the effects of allelopathic water extracts of fenugreek, coriander and sorghum tank mixed with reduced dose of glyphosate herbicide compared to full dose of glyphosate alone on controlling Orobanche crenata in some faba bean cultivars.

*Economic Affairs Sector, Ministry of Agriculture and land reclamation 2020.

\section{MATERIALS AND METHODS}

This study was carried out on an Orobanche naturally infested soil at Sakha Research Station, Kafr El shiekh governorate, Egypt, during 2017/18 and 2018/19 seasons. Plant water extracts of fenugreek, coriander and sorghum crops in addition to glyphosate herbicide were used.

\section{Preparation of crop water extracts:}

Plants of fenugreek, coriander and sorghum were harvested, air dried for two weeks in the shade and stored at room temperature. The dried plants were grounded into a fine powder. 10 grams of the powder were extracted with $100 \mathrm{ml}$ of distilled water for $\mathbf{2 4}$ hours in a shaker. The mixture was filtered through a muslin cloth and finally through filter paper to obtain one concentration of extracts (10\%).

\section{experimental treatments:}

Three faba bean cultivars (Misr1, Giza843 and Sakha1) were foliarly 
sprayed with the extracts and glyphosate herbicide twice 50 and 70 days after sowing (DAS) as follows:

- Glyphosate at full recommended rate $\left(75 \mathrm{~cm}^{3} / \mathrm{fed}\right)$.

- Glyphosate at a rate of $40 \mathrm{~cm}^{3}$ mixed with $20 \mathrm{~L}$ of fenugreek water extract Ifed.

- Glyphosate at a rate of $40 \mathrm{~cm}^{3}$ mixed with $20 \mathrm{~L}$ of coriander water extract Ifed.

- Glyphosate at a rate of $40 \mathrm{~cm}^{3}$ mixed with $20 \mathrm{~L}$ of sorghum water extract Ifed.

- Untreated (water spray only) control.

\section{Crop management:}

Faba bean cultivars, Misr1, Giza843 (Orobanche tolerant) and Sakha1 (Orobanche susceptible) were planted on November 5 in both seasons. Glyphosate herbicide either alone or in combination with crop extracts (as donor allelopathic plants) were foliarly applied 50 and 70 days after sowing on faba bean plants, using knapsack sprayer CP3 with $200 \mathrm{~L}$ water Ifed. The experimental soil analyses are giving in Table 1 . Each experiment was fertilized with organic manure $(20 \mathrm{~m} 3 / \mathrm{fed})$, phosphorus fertilizer (calcium super phosphate15\% P2O5) was applied once at $200 \mathrm{~kg} / \mathrm{fed}$. during planting. Nitrogen fertilizer was added in $50 \mathrm{~kg}$ /fed. before the first irrigation, Potassium fertilizer was added at a rate of $48 \mathrm{~kg} \mathrm{K2O/fed} \mathrm{at} 60$ days after sowing. The experiment was laid out in a split plot design with three replications. Cultivars were randomly arranged in the main plots, while broomrape control treatments occupied the sub plots that contained four ridges $60 \mathrm{~cm}$ apart and three meters long. Seeds were planted on one side of the ridge in hills $20 \mathrm{~cm}$ apart and one seed per hill. Data recorded at harvest were:

\section{Orobanche characters:}

- Orobanche spikes number, height (cm) and weight $(\mathrm{g} / \mathrm{m} 2)$.

\section{Faba bean cultivars}

- Plant height (cm), number of branches, pods, seeds/plant and seed weight/plant (g), using a random sample of 10 guarded plants. However, Seed yield was determined from the two middle ridges of each sub-plot, and transformed to (ardab (fed.) 1 ardab $=155 \mathrm{~kg}$.

\section{Statistical analysis:}

Data were subjected to analysis of variance according to (Gomez and Gomez (1984). Treatment means were compared by L.S.D. at 0.05 level of probability. All statistical analysis was performed using analysis of variance technique MSTAT-C computer software package. The weather data during the two growing seasons are presented in (Table 2). The Origin, pedigree and reaction to 0 . crenata for the studied genotypes are presented in (Table 3).

Table 1. Soil chemical and physical analyses of the experimental site

\begin{tabular}{|c|c|c|c|c|c|c|c|c|c|}
\hline Season & $\begin{array}{c}\text { Organic } \\
\text { Matter\% }\end{array}$ & $\begin{array}{c}\text { Soil } \\
\text { PH }\end{array}$ & $\begin{array}{c}\text { Sand } \\
\%\end{array}$ & $\begin{array}{c}\text { Silt } \\
\%\end{array}$ & $\begin{array}{c}\text { Clay } \\
\%\end{array}$ & $\begin{array}{c}\text { Textural } \\
\text { Class }\end{array}$ & $\begin{array}{c}\text { N } \\
\text { ppm }\end{array}$ & $\begin{array}{c}\text { P } \\
\text { Ppm }\end{array}$ & $\begin{array}{c}\text { K } \\
\text { Ppm }\end{array}$ \\
\hline $2017 / 18$ & 0.53 & 8.14 & 19.83 & 31.93 & 49.24 & Clay & 17.35 & 6.83 & 259.36 \\
\hline $2018 / 19$ & 0.55 & 8.11 & 16.44 & 32.63 & 50.93 & Clay & 18.30 & 6.18 & 296.35 \\
\hline
\end{tabular}


T.S. Mohamed, et al.,

Table 2: Monthly average temperature, relative humidity and solar radiation during $2017 / 2018$ and $2018 / 2019$ seasons.

\begin{tabular}{|c|c|c|c|c|c|c|}
\hline & \multirow{2}{*}{ Month } & \multicolumn{2}{|c|}{ Air Temperature $\left({ }^{\circ} \mathrm{C}\right)$} & \multicolumn{2}{|c|}{ Relative Humidity (\%) } & \multirow{2}{*}{$\begin{array}{c}\text { Solar Radiation } \\
\text { (Mega joule /m2) }\end{array}$} \\
\hline & & Max. & Min. & $7: 30$ & $13: 30$ & \\
\hline \multirow{4}{*}{ } & November & 24.00 & 10.50 & 86.70 & 53.00 & 13.0 \\
\hline & December & 20.19 & 6.44 & 86.00 & 61.13 & 15.2 \\
\hline & January & 18.16 & 8.35 & 77.50 & 60.26 & 15.0 \\
\hline & February & 17.54 & 9.57 & 75.61 & 62.05 & 15.5 \\
\hline \multirow{4}{*}{ 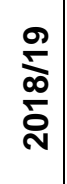 } & November & 25.32 & 15.46 & 89.20 & 61.80 & 13.0 \\
\hline & December & 21.38 & 10.57 & 84.74 & 60.75 & 15.0 \\
\hline & January & 19.20 & 7.60 & 90.95 & 65.40 & 15.2 \\
\hline & February & 20.80 & 8.95 & 90.22 & 63.86 & 15.5 \\
\hline
\end{tabular}

Table 3. The origin, pedigree and reaction of faba bean cultivars to Orobanche crenata.

\begin{tabular}{|l|c|c|c|}
\hline \multicolumn{1}{|c|}{ Genotype } & Origin & Pedigree & Reaction to Orobanche \\
\hline Misr 1 & FCRI $^{*}$ & Giza $3 \times 123 A / 45 / 76$ & Tolerant \\
\hline Giza 843 & FCRI & $561 / 2076 / 85 \times 461 / 845 / 83$ & Tolerant \\
\hline Sakha 1 & FCRI & $716 / 724 / 88 \times 620 / 283 / 85$ & Susceptible \\
\hline
\end{tabular}

*Field Crops Research institute, ARC, Giza.

\section{RESULTS AND DISCUSSION}

Data in Table (4) showed means values of Orobanche spike number, height and weight at harvest as affected by foliarly application twice 50 and 70 DAS of glyphosate herbicide alone at the recommended dose and almost half dose of the herbicide along with water extracts of either of fenugreek, coriander or sorghum. Results showed that glyphosate either alone or combined with water extracts of fenugreek, coriander or sorghum led to remarkable decreases in Orobanche spikes number, height and weight compared with the untreated in both seasons. Reductions percent in Orobanche number and weight due to glyphosate applied alone at full recommended dose were 87.0 and $\mathbf{8 4 . 0 \%}$ of those found at untreated treatment. In this connection, application of a reduced (half) dose of the herbicide mixed with plant extracts of either fenugreek or coriander or sorghum gave as good results as did the full dose alone, recording 84 and 82,82 and 80,82 and $79 \%$ reductions in Orobanche spikes number and weight over the two seasons, respectively compared with the untreated control Table 4. Differences among those broomrape control treatments did not reach the level of significance indicating that glyphosate recommended dose $\left(75 \mathrm{~cm}^{3} / \mathrm{fed}\right)$ could be reduced to only $40 \mathrm{~cm}^{3} / \mathrm{fed}$ accompanied with any of the water plant extracts used in this study infavor of fenugreek.

Data in Table 4 showed clearly that the two Orobanche tolerant cultivars (Misr1 and Giza843) recorded only 36, 39 and 38, $41 \%$ for number and weight of Orobanche spikes/m2, respectively compared with those found on the susceptible cultivar (Sakha1). Moreover, Orobanche spikes on the tolerant cultivars were much shorter than those on the susceptible one. 


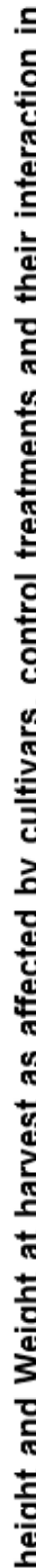

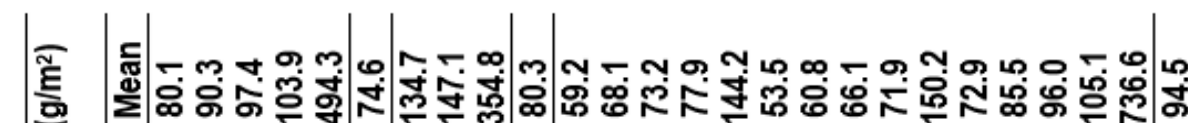

(9)

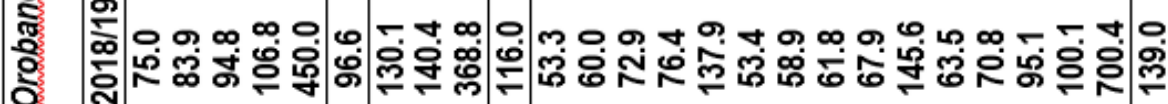

$\infty$

m

ᄃ कิ

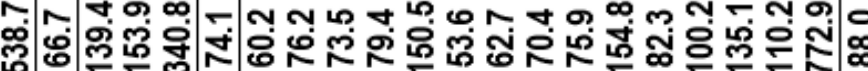

$m$ m 0 o d

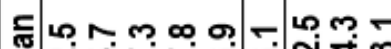

0 - 0 ก

m

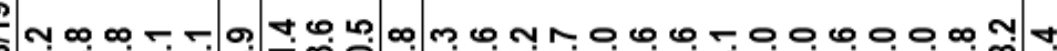

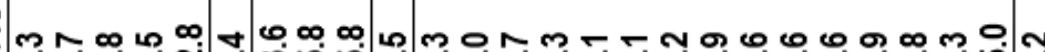
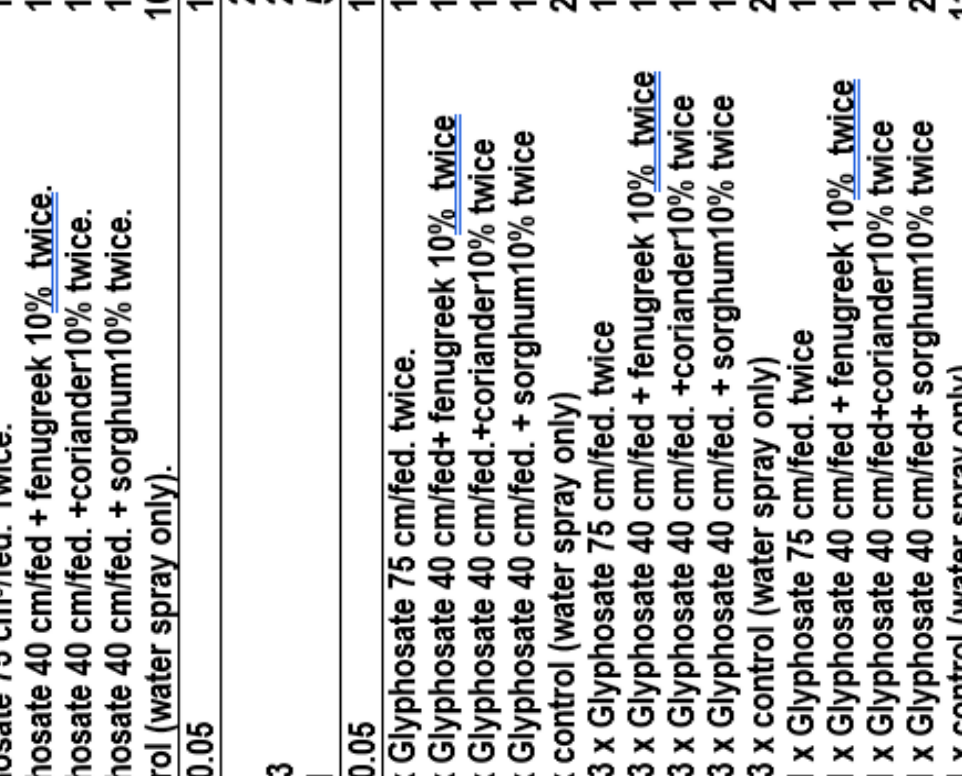

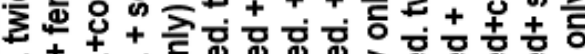

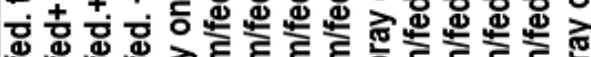
원

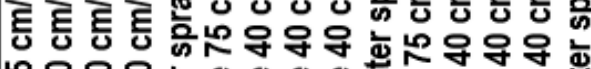

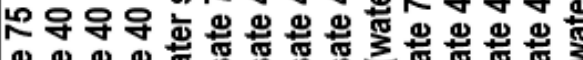

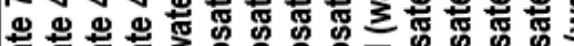

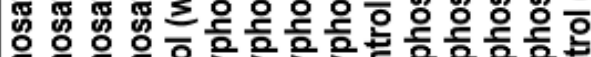

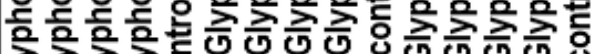

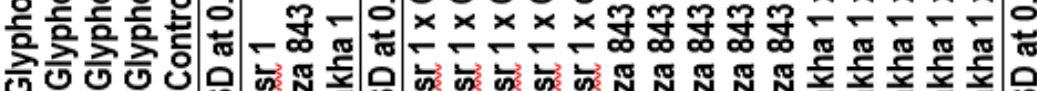
|บ் 
Results (Table 4) also indicated that tolerant cultivars can be grown with no herbicide and/or plant extract applications, since no significant differences were detected among the herbicide spray treatments and the untreated one in number and weight of Orobanche spikes/m2 at harvest. On the other hand, the susceptible cultivar have to be sprayed with glyphosate herbicide either alone at full recommended dose $\left(75 \mathrm{~cm}^{3}\right.$ or at reduced (half) dose mixed with any of fenugreek, coriander or sorghum crop water extracts so as to achieve as good Orobanche control levels as those obtained with the tolerant cultivars. These findings agreed with those reported by Abbes et al., 2007 and 2009, Alsaadawi et al., 2013, Madany and Khalil 2017 and Fernandez - Aparicio et al., 2012 and 2014).

It is worthy noting that, reducing glyphosate dose would be important to avoid the harmful effect to faba bean plants due to the irregular herbicide distribution that commonly occurred in farmers fields.

Data in Tables 5 and 6 showed that, all glyphosate application significantly increased plant height $(\mathrm{cm})$, number of branches, number of pods and seeds/plant, seed weight/plant(g) and seed yield/feddan compared with untreated (water spray only) in both seasons. Applying glyphosate at full recommended rate $\left(75 \mathrm{~cm}^{3} / \mathrm{feddan}\right)$ twice 50 and 70(DAS) gave the tallest plants and greatest seed yield as well as its attributes followed by applying glyphosate at $40 \mathrm{~cm}^{3} / \mathrm{feddan}$ twice 50 and 70 (DAS) in combination with $20 \mathrm{~L}$ water extract/feddan of fenugreek or coriander or sorghum in both seasons than untreated (water spray only). No significant differences in plant height/plant, seed yield/feddan and its attributes between all glyphosate treatments over the two growing seasons. In this connection, data in Table 6 shows applying glyphosate at a rate $40 \mathrm{~cm}^{3} / \mathrm{feddan}$ twice 50 and 70 (DAS) in combination with $20 \quad \mathrm{~L}$ water extract/feddan of fenugreek or coriander or sorghum decreased seed yield/feddan by $3.6,6.0$ and $9.7 \%$ respectively, than applying glyphosate at full recommended rate twice 50 and 70 (DAS) over the seasons. Misr1 and Giza843 cultivars produced the highest values of plant height and seed yield/feddan as well as its attributes compared to Sakha1 in both seasons. At the same time, Misr1 and Giza843 cultivars increased seed yield/feddan by 340 and $325 \%$ compared to Sakha1 over the two seasons.

Results (Tables 5 and 6) also indicated that tolerant cultivars can be grown with no herbicide and/or plant extract applications, since no significant differences were detected among the herbicide spray treatments and the untreated one in plant height/plant and seed yield/fed as well as its attributes. On the other hand, the susceptible cultivar have to be sprayed with glyphosate herbicide either alone at full recommended dose $\left(75 \mathrm{~cm}^{3}\right.$ or at reduced (half) dose mixed with any of fenugreek, coriander or sorghum crop water extracts so as to achieve as good seed yield/fed and its attributes as those obtained with the tolerant cultivars. These results confirmed Madany and Khalil (2017) he found that, fenugreek seed extracts up to $1.0(w / v)$ efficiently enhanced the growth as well as the chlorophyll content of faba bean. The highest values of the findings are in agreement with reported by Abd ElKader (2013) and Attia et al., (2013), Hassanien et al., (2016). Who reported that, faba bean genotypes differed from each other in their seed yield regarding Orobanche infestation and that broomrape infestation affected plant and yield character ristics to different degrees. 


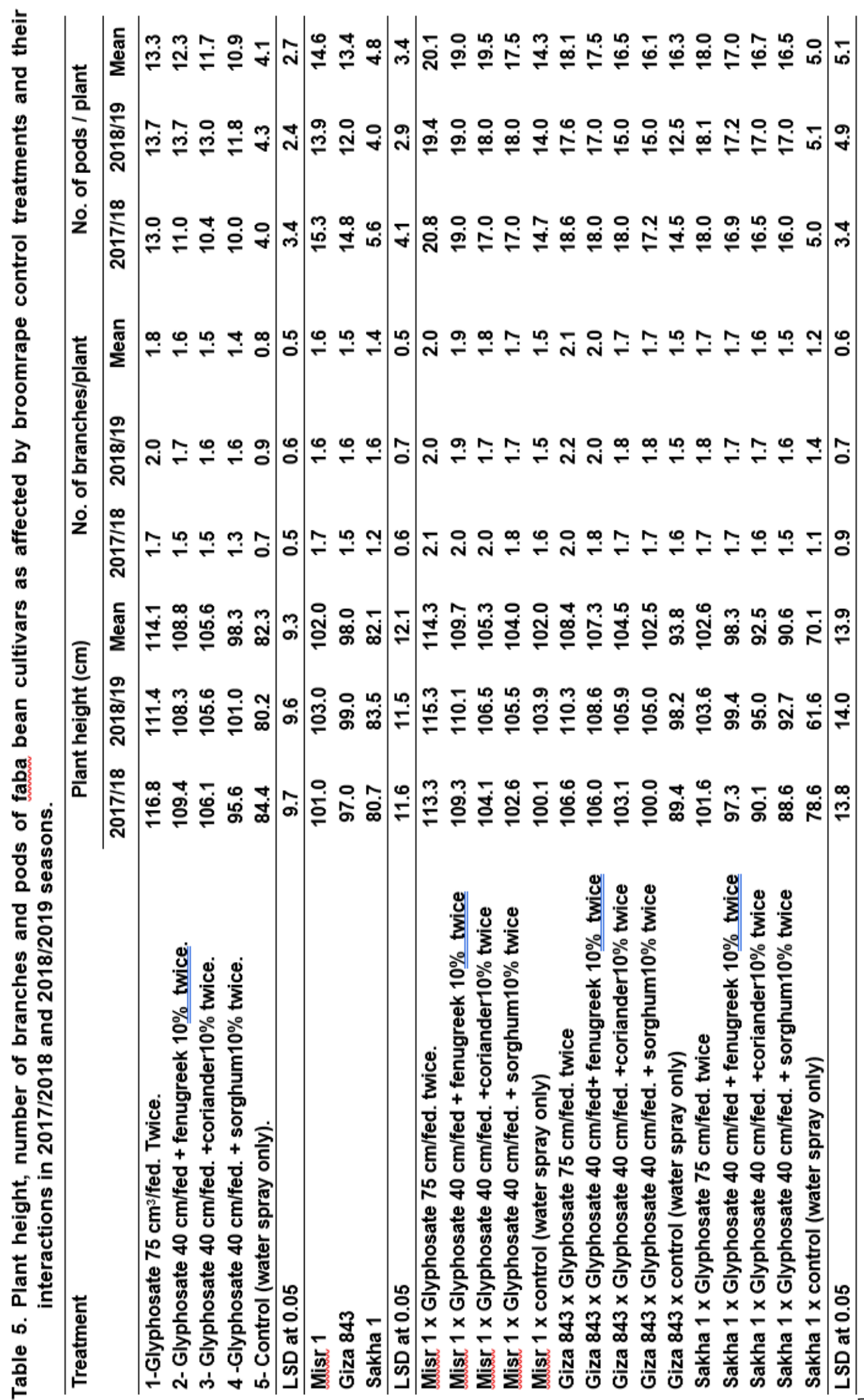


列

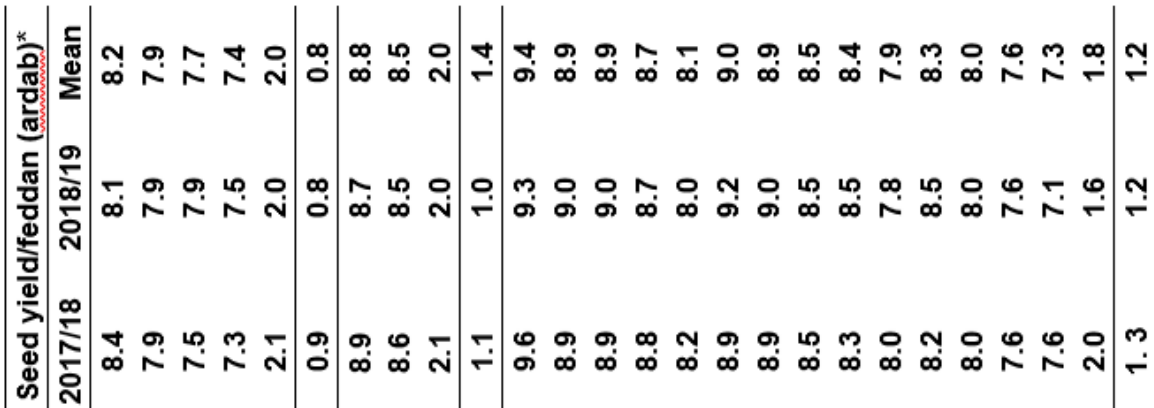

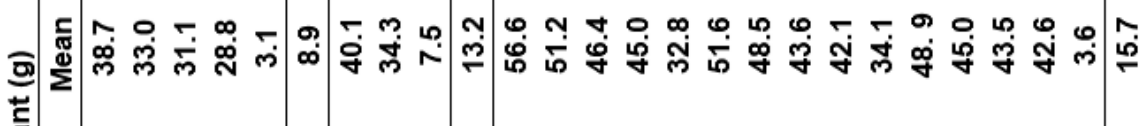

흥

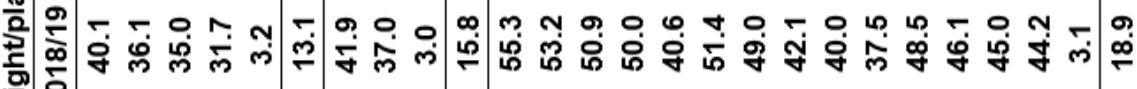
จิ

ฐ్

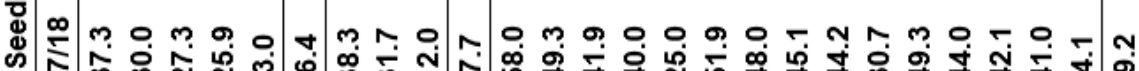

韩

“

จृ

心

음

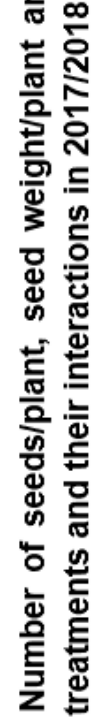

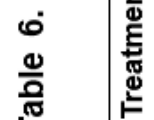

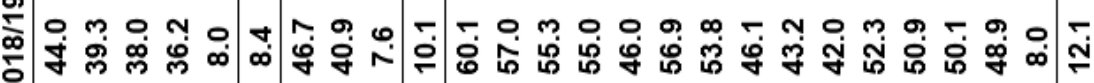

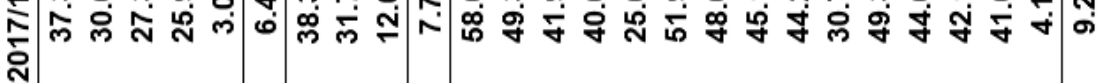
z 


\section{REFERENCES}

Abbes, Z., M. Kharrat, P. Simier and W. Chaibi (2007). Characterization of resistance to crenata broomrape (Orobanche crenata) in a new small of Tunisian faba bean. Phyto protection 88: 83-92.

Abbes, Z., M. Kharrat, P. Delavault, W. Chaibi and P. Simier (2009). Osmoregulation and nutritional relationships between Orobanche foetida and faba bean. Plant signal Behavior 4: 336-338.

Abd El-Kader, Azza F. (2013). Inheritance studies and molecular marker for related characters to Orobanche resistance in faba bean. Ph.D. Thesis. Fac. Agric., Zagazig Uni. Egypt.

Alsaadawi, I.S, A. Khaliq, N. R. Lanmod and A. Matloob (2013). Weed management in broad bean (vicia faba) through allelopathic sorghum bicolor (L) Moench residues and reduced rate of a pre-plant herbicide. Allelopathy Journal 32 (2): 203-212.

Attia Sabah, M., M.M. El-Hady, H.A. Sabe, M.A. Omer, S.A. Khalil, SamiaA. Mahmoud, A.A.M. Ashrei, Rehab A.M. bdEIrahman, M. A. M. Ibrahim, Zeinab E. Ghareeb, T. S. El-Marsafawy, E. H. El-Harty, E. A. A. El-Emam, F. H. Shalaby, A.G. Helal, A.M. El-Garhy, E.M. Rabie, M. Abdeen, M. ElNoby, Kh. M. M. Yamani, H. T. Abd El-Aal, M. A. Ibrahim, R. A. Abo Mostafa, W. ElRodeny, K.M. Morsy, Noher, A. Mahmoud, Azza F. El-Sayed and Hend A. Ghannnam (2013) Misr 3, a new Orobanche tolerant faba bean variety. Egypt. J. Plant Breed.17 (6): 143-152.

Hassanien, Aziza M., Sabah M. Attia, Rehab A. M. Abd El-Rahman and M. A. M. Ibrahim (2016). Orobanche crenata effects on some faba bean genotypes, the genetic variation among three isolates and its chemical constituents. Egypt. J. Plant Breed, 20 (1): 105-118.
Ennami, M., Z.B. Fatima, F. Gabon and A. Rabha (2017). Host differentiation and variability of Orobanche crenata populations from legume species in Morocco as revealed by crossinfestation and molecular analysis. Pest Manag. Sci 78: 1753-1763.

Farooq, M., K. Jabran, Z. A. Cheema, A. Wahid and K.H.M. Siddique (2011). Exploiting Allelopathy for sustainable agriculture. Pest Manag. Sci., 67: 493506.

Fernandez, A., M. Paricio, T. Kisugi, X. Xie and D. Rubiales (2014). Resistance available for faba bean breeding. Journal of Agri. And food chemistry 62: 7063-7071.

Fernandez, A., M. Paricio, A. Moral, M. Kharrat and D. Rubiales (2012). Resistance against broomrapes (Orobanche and Phelipanche Spp.) in faba bean (Vicia faba) based on low induction of broomrape seed germination. Euphytica186:897-905.

Fernandez Aparicio M., F. Flores and D. Rubiales (2016). The effect of Orobanche crenata infection severity in faba bean, field pea, and grass pea productivity. Front plant Sci 7:1409. http://doi.org/10.3389/fpls.2016. 01409.

Fouad, M., N. Mohamed, H. Aladdin, A. Ahmed, Z. Xuxiao, B. Shiying and Y. Tao (2013). Faba bean. Pp 113-136. http:II doi.org/10.1016/ b978-0-12397935-3. 00005-0.

Gomez, K. A. and A. A. Gomez (1984). "Statistical procedures for Agricultural Research"2 nd edition. John Wiley \& Sons, Inc., New York, USA.

Habimana, S., K. Murthy, V. Hatti and A. Nduwumuremyi (2013). Management of Orobanche in field crops-a review. Sci J crop Sci 2: 144-158.

Jabran, K., Z. A. Cheema, M. Farooq, S. $M$. A. Basra, M. Hussain and $H$. Rehman (2008). Tank mixing of 
T.S. Mohamed, et al.,

allelopathy crop water extracts with pendimethalin helps in the management of weeds in canola (Brassica napus) field. Int. J. Agric. Biol.10:293-296.

Maalouf, F., S. Khalil, S. Ahmed, A. N. Akintunde, M. Kharrat, K. El Shama and R.S. Malhotra (2011). Yield stability of faba bean lines under diverse broomrape prone production environments. Field Crop Research 124:288-294.

Madany, M.M.R. and R.R. Khalil (2017). Fenugreek seed extract enhanced the growth of Vicia faba and zea mays seedlings. Egypt. J. Bot. 57 (2:) 263377.

Rubiales, D. (2010). Faba beans in sustainable agriculture. Field crops Res 115:201-2020

Rubiales, D., A. Fernandez and M. Paricio (2012). Innovations in parasitic weed management in legume crops. Agro. Sustain Dev 32:433449.https://doi.org/10.1007/s10681-0067399-1 
استخدام بعض المستخلصات النباتية خلطا مع معدل منخفض من مبيد الجليفوسيت لمكافحة الهالوك فى الفول البلدى

طارق صابر محمد(1)، على على حسن شرشر (2)، سامـح حمادة السيد حمادة(3) (1) قسم بحوث المحاصيل البقولية - معه بحوث المحاصيل الحقلية- مركز البحوث الزراعية-الجيزه- مصر.

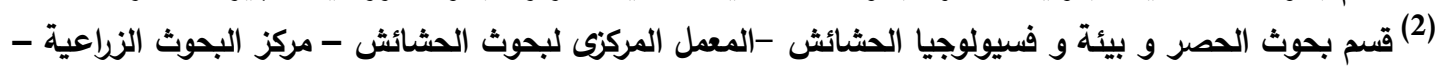

$$
\text { الجيزه - مصر. }
$$

(3) قسم وقاية النبات - كلية الزراعة - جامعة الازهر بالقاهرة - مصر.

الملخص العربي

اجريت تجربة حقلية في ارض موبوءة بالهالوك بمحطة البحوث الزراعية بسخا- كفر الثيخ سمصر خلال موسمي

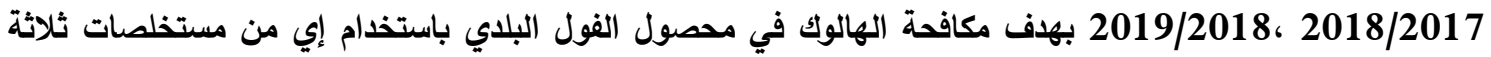

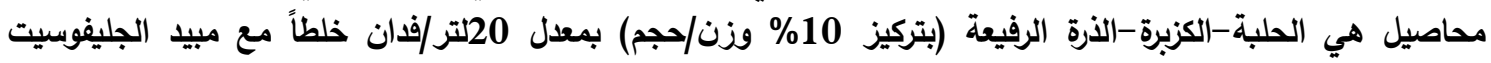

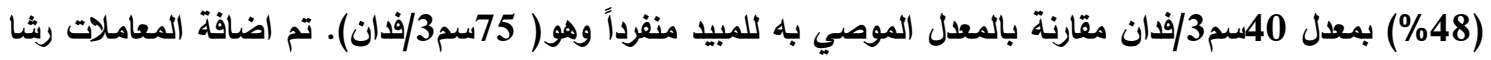

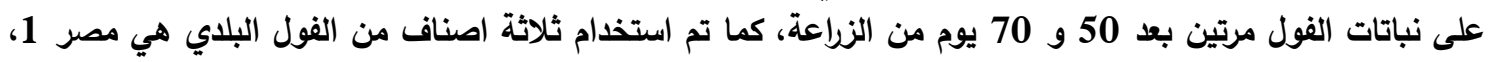

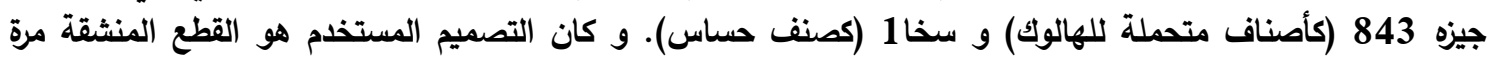

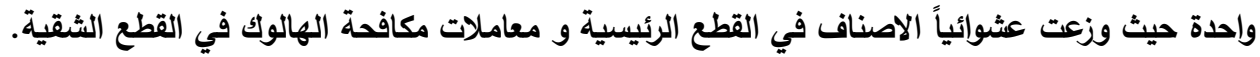

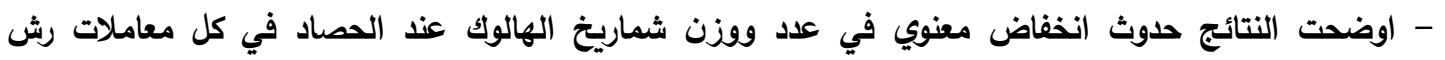

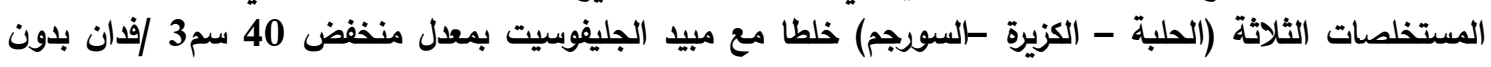

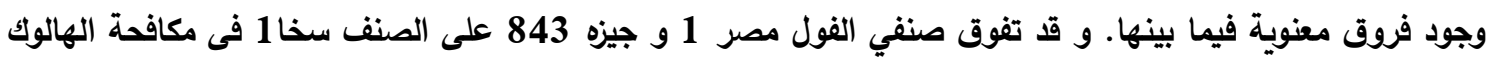

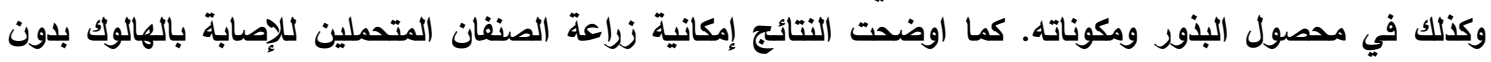

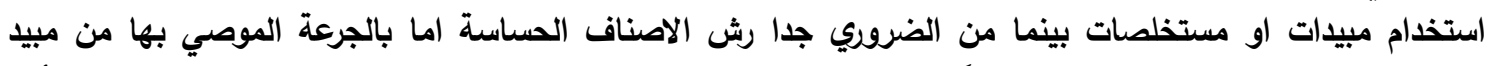

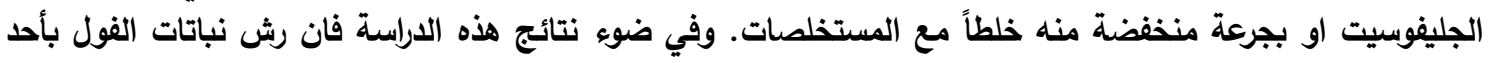

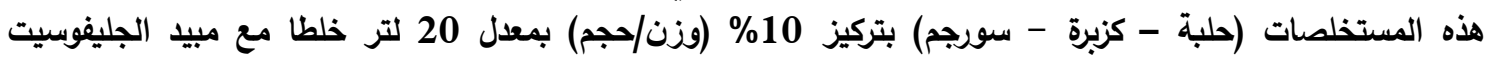

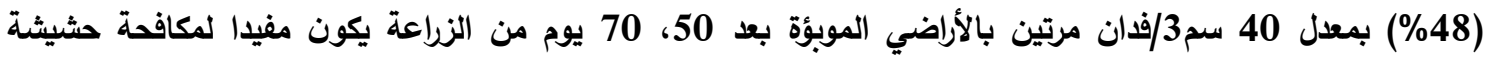
الهالوك والحصول على محصول افضل من الفول البلدي. 